\title{
Classification of Broadleaf Weeds Using a Combination of K-Nearest Neighbor (KNN) and Principal Component Analysis (PCA)
}

\author{
Alfry Aristo Jansen Sinlae ${ }^{1 *}$, Dedy Alamsyah ${ }^{2)}$, Lilik Suhery ${ }^{3)}$, Fryda Fatmayati ${ }^{4)}$ \\ 1) Universitas Katolik Widya Mandira, Indonesia \\ 2) Universitas Muhammadiyah Tangerang, Indonesia \\ ${ }^{3}$ Sekolah Tinggi Teknologi Payakumbuh, Indonesia \\ ${ }^{4)}$ Sekolah Tinggi Teknologi Kedirgantaraan, Indonesia \\ 1)alfry.aj@unwira.ac.id, ${ }^{2)}$ dedy.alamsyah@umt.ac.id, ${ }^{3}$ liliksuhery@ sttpyk.ac.id, ${ }^{4}$ fryda.fatmayati@ sttkd.ac.id
}

Submitted : Dec 29, 2021 | Accepted : Jan 5, 2022 | Published : Jan 6, 2022

\begin{abstract}
Palm oil is one of the leading commodities in Indonesia. Oil palm yields can be influenced by several factors, one of which is proper weed control. Uncontrolled weeds can damage oil palm plantations. To be able to manage and control weeds, especially large leaf weeds, it is necessary to know the types of weeds. However, not all farmers have knowledge about the types of weeds. For that we need a system that can help identify broadleaf weeds based on leaf images using image processing. So this study aims to build a large leaf weed classification system using a combination of the K-Nearest Neighbor (KNN) and Principal Component Analysis (PCA) algorithms. PCA is used as feature extraction based on the characteristics formed from each spatial property. PCA can be used to reduce and retain most of the relevant information from the original features according to the optimal criteria. The results of the information will then be used by KNN for learning by paying attention to the closest distance from the object. Based on the test results, the developed model is able to produce an accuracy of $90 \%$. Principal Component Analysis (PCA) and KNearest Neighbor $(\mathrm{KNN})$ algorithms can be used in the classification process properly. Accuracy results are strongly influenced by the amount of training data and test data as well as the quality of the image used.
\end{abstract}

Keywords: Broadleaf weed; Classification; Image processing; K-Nearest Neighbor; Principal Component Analysis.

\section{INTRODUCTION}

Based on the United State Department of Agriculture 2019, regarding world palm oil production, Indonesia is the largest palm oil producing country in the world (Pradhana, 2020). However, palm oil production may decline based on several factors. One of the factors inhibiting oil palm yields in the field experienced by farmers is improper weed control. Weeds are plants that interfere with the growth of cultivated plants or harm human interests (Imaniasita, Liana, \& Pamungkas, 2020). Weed growth can reduce oil palm fruit bunch production by up to $20 \%$ (Saleh, Dibisono, \& Gea, 2020). The presence of weeds in cultivated plants results in competition in terms of taking water, nutrients, growing space and sunlight which can harm plants. The types of weeds that grow dominantly in oil palm plantations differ from one place to another, weed dominance is caused by differences in environmental characteristics from one place to another (Dahlianah, 2019). The types of weeds in oil palm that are cultivated on wetlands/peat are different from the weeds that grow around oil palms that are cultivated on dry land, so the handling is also different. Weed management depends on the physiology and type of weed. Weeds that are often found in oil palm plantations on dry land are broadleaf weeds. Weeds need to be handled properly, this is because weeds are a breeding ground for diseases and pests. Some weeds that produce nectar can be a breeding ground for predatory insects or a breeding ground for predators, so wise weed management can benefit oil palm farmers (Imaniasita et al., 2020). To be able to manage and control weeds, especially large-leaved weeds, it is necessary to know the types of weeds. However, not all farmers have knowledge about the types of weeds. For that we need a system that can help identify the type of broadleaf weed based on the image of the leaves, so image processing can be a solution to this problem.

*name of corresponding author 
Digital image processing is a field that studies how an image is formed, managed, and analyzed to obtain useful information (Dix \& Müller, 2021). From image processing can produce information that can be useful in helping human work (Mulyanto et al., 2020). One application of image processing is image classification. Image classification is the process of grouping the pixels of an image into several classes, this is done in order to describe the recognizable characteristics of the image (Borman, Priopradono, \& Syah, 2017). Classification can help understand diversity better (Prasetyawan et al., 2018). One of the well known order calculations utilized in picture characterization is K-Nearest Neighbor (KNN). KNN is a methodology used to arrange specific articles dependent on learning information that has the nearest distance to the item ( $\mathrm{Li}$ et al., 2019). The benefits of the KNN calculation are effortlessness of execution and quick calculation time (Lubis, Sihombing, \& Mawengkang, 2020).

The purpose of this study is to build an image processing application for the classification of broadleaf weeds. The classification method used is KNN. However, KNN can work well if it gets information or characteristics of the image classes to be classified, so optimal feature extraction is needed. To optimize and improve the accuracy of the KNN algorithm, KNN is combined with the Principal Component analysis (PCA) algorithm which is used for feature extraction. PCA is a strategy that can be utilized to diminish and hold the majority of the applicable data from the first highlights as per the ideal measures (Justiawan, Sigit, \& Arief, 2017). PCA can work on information through straight changes in order to shape a framework that has new arranges that produce greatest fluctuation (Borman \& Priyopradono, 2018). So in this study the classification of broadleaf weeds was developed using a combination of KNN and PCA algorithms.

\section{LITERATURE REVIEW}

Image processing is firmly connected with the development of new factors to consolidate and decrease the components of the handled elements or this term is known as feature extraction (Lee \& Tseng, 2018). Classification requires reducing the dimensions of each group of object characteristics, including in the preprocessing process so that certain patterns can be identified (Agustin \& Dijaya, 2019). The KNN algorithm has been popularly used as an approach used in image classification. KNN has results that show it can classify images efficiently and also successfully identify with accuracy and have high resilience (Vaishnnave, Devi, Srinivasan, \& Jothi, 2019)(Tanjung \& Wijaya, 2020)(Alkababji \& Jbaar, 2021). Several previous studies have shown that KNN can produce high accuracy. Such as research on face classification with KNN which produces an accuracy of $81 \%$ with $\mathrm{k}=1$ (Wirdiani et al., 2019). Furthermore, research on the classification of tomato maturity using K-Nearest Neighbor which produces the highest level of accuracy reaches $92.5 \%$ with the $\mathrm{k}$ parameter used as many as 3 (Sanjaya, Pura, Gusti, Yanto, \& Syafria, 2019). Another study, regarding the classification of butterfly species with the KNN algorithm, which produces the highest accuracy rate of $91.1 \%$ (Andrian, Maharani, Muhammad, \& Junaidi, 2020). There is also a research on the application of KNN to image classification in medicinal plant classification which is focused on the shape features of the plant (Ionel-bujorel, Ancuceanu, Enache, \& Vasilăţeanu, 2017). The existing research shows that KNN is able to classify images well, but for the classification of similar objects the accuracy results are reduced. So, it is necessary to improve and add methods for classification based on features formed from objects that can reduce and maintain appropriate information from the original characteristics according to the criteria that can be extracted.

Principal Component Analysis (PCA) is an approach that can reduce dimensions that can be used in image processing. PCA can take advantage of the covariance framework and eigenvalues so that it can dig up unrelated information on eigenvectors that make information from objects to what extent the information fluctuates (Borman \& Priyopradono, 2018). PCA has been implemented to reduce the main features so that problems in retrieving information from the image. The combination of PCA and KNN is proven to be able to increase the accuracy value (Nikita, Sadawarti, \& Kaur, 2020). The combination of PCA and KNN in the RGB and HSV color spaces has a higher accuracy value than using only KNN (Justiawan et al., 2017). In this paper, a system is developed for the classification of broadleaf weeds by combining PCA which is used to provide information on the characteristics of each object and KNN will use this information for learning based on the closest distance to the object.

\section{METHOD}

To develop a broadleaf weed classification system with a combination of KNN and PCA algorithms, it is necessary to carry out the stages carried out in the study. Fig. 1 below is the stages carried out in the research. 


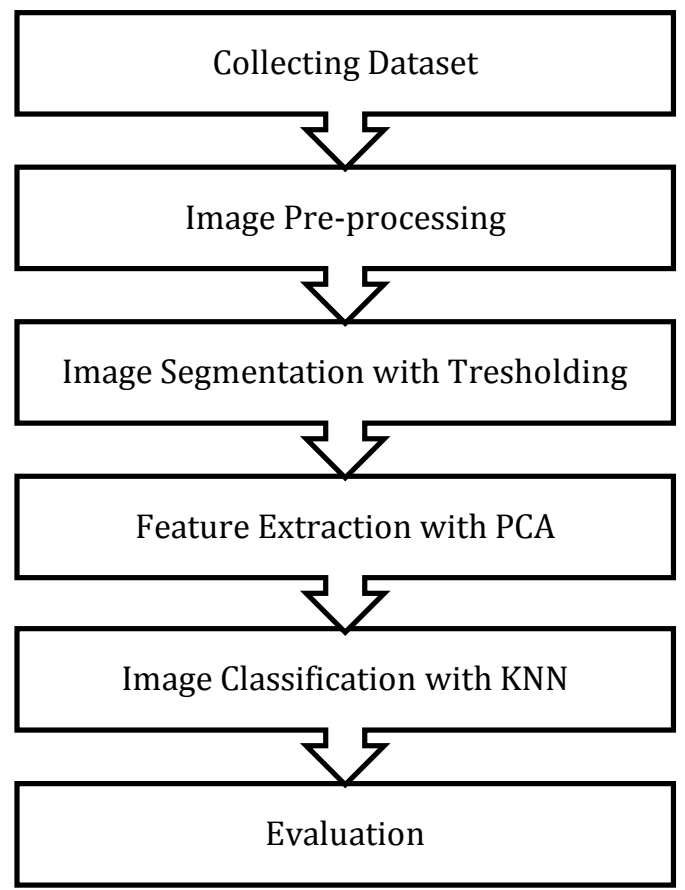

Fig. 1 Research Stages

\section{Collecting Dataset}

At this stage, image data collection will be carried out or called a dataset. The dataset is a collection of broadleaf weed images that will later be used for training data and test data. There are many types of broadleaf weeds that grow dominantly in oil palm plantations, but there are four types of broadleaf weeds that are often encountered and require special control so as not to interfere with the productivity and quality of oil palm. There are 4 types of large leaf weeds used as classes in the classification carried out, namely Mikania micrantha, Ageratum conyzoides, Asystasia gangetica and Borreria alataImages of broadleaf weeds used as datasets were collected from the internet. The quality and number of datasets will affect the classification results, therefore preparation is needed in collecting them (Borman \& Wati, 2020). In this study, the dataset used was 160 images. Distribution of datasets using a trial-and-error approach (Chen, Song, Liu, Yang, \& Li, 2020), which determines the structure of the model by dividing the data into 50\% training and 50\% testing. So, the training data used are 80 training data and 80 test data. If there are 4 types of weeds, then for each medicinal plant there are 20 training data and 20 test data.

\section{Image Pre-processing}

The next stage is the image preprocessing process, where image cropping will be carried out to facilitate the model in recognizing objects and converting the original image into a binary image. This is intended to make it easier to do image segmentation.

\section{Image Segmentation with Thresholding}

Image segmentation serves to separate one object from another. Separation is carried out based on territorial boundaries that have the same shape or arrangement. The output of this process is a binary image, where the desired object has a value of 1 (white color), while the background value is 0 (black color). Image segmentation in this paper uses thresholding technique. Thresholding aims to find the right threshold value, in order to separate objects from the background (Borman, Rossi, et al., 2021). This image transformation process into binary form aims to make the feature extraction process easier.

\section{Feature Extraction with PCA}

Principal Component Analysis (PCA) works dependent on numerical computations that change factors that have a relationship into a bunch of elements with a modest number or called the fundamental part (Borman, Napianto, et al., 2021). These stages produce a few eigenvectors which are a blend of all the element varieties contained in all information. In the event that the article utilized is a leaf picture, then, at that point, the eigenvectors are frequently called eigenfaces. To do this, the information or picture to be diminished correspondingly should

*name of corresponding author 
be changed over into a bunch of segment grids $\Gamma_{1}, \Gamma_{2}, \Gamma_{3}, \ldots \Gamma_{M}$ where $\mathrm{M}$ is the quantity of tests accessible. The normal of every information can be determined through the accompanying advances:

The initial step is to set up the information by making a set $\mathrm{S}$ comprising of all the preparation images.

$$
\left(\Gamma_{1}, \Gamma_{2}, \Gamma_{3}, \ldots \Gamma_{\mathrm{M}}\right) \mathrm{S}=\Gamma_{1}, \Gamma_{2}, \Gamma_{3}, \ldots \Gamma_{M}
$$

Next, take the middle value ( $\Psi$ ) by using the following equation:

$$
\Psi=\frac{1}{M} \sum_{n=1}^{M} \Gamma_{n}
$$

Then find the difference $(\Phi)$ between training data $(\Gamma \mathrm{i})$ and the average value using the following formula:

$$
\text { ( } \Psi) \Phi_{i}=\Gamma_{i}-\Psi
$$

The next step is to determine the value of the covariance matrix $(\mathrm{C})$ with the following equation:

$$
\mathrm{C}=\frac{1}{\mathrm{M}} \sum_{n=1}^{M} \Phi_{n} \Phi_{n}^{T}=A A^{T}
$$

Next, look for the eigenvalues $(\lambda)$ and eigenvectors) of the covariance matrix $(C)$ using the following equation:

$$
\mathrm{C} \times v_{i}=\lambda_{i} \times v_{i}
$$

The last step, after the eigenvector (v) is obtained, then the next step is to calculate the eigenface $(\mu)$ through the following equation:

$$
\mu_{i}=\sum_{k=1}^{M} v_{l k} \Phi_{k} \quad 1=1, \ldots, \mathrm{M}
$$

\section{Image Classification with KNN}

The k-nearest neighbors (KNN) algorithm is a grouping approach dependent on the nearest learning information to the item being handled. The manner in which KNN works is by entering information into a complex space, where each aspect addresses an information highlight. To apply the past KNN, the test, for instance $\mathrm{X}$ is made to look like the state of a component vector $(\mathrm{X} 1, \mathrm{X} 2, \ldots \mathrm{Xm})$. The example is utilized as the general preparing test. Then, at that point, ascertain the comparability between the preparation test and the test $\mathrm{X}$ by taking examples at to-I (di1, di2, ... . faint) then, at that point, the condition is determined by the accompanying recipe:

$$
\operatorname{Similarity}\left(X, d_{i}\right)=\frac{\sum_{j=1}^{m} X_{j} \cdot d_{i j}}{\sqrt{\left(\sum_{j=1}^{m} X_{j}\right)^{2}} \sqrt{\left(\sum_{j=1}^{m} d_{i j}\right)^{2}}}
$$

Next, from k samples that have the greatest similarity and then calculate the probability using the following formula:

$$
P\left(X, C_{j}\right)=\sum_{d} \operatorname{Similarity}\left(X, d_{i}\right) \cdot y\left(d_{i}, C_{j}\right)
$$

Where $y\left(d_{i}, C_{j}\right)$ is an attribute of the category function with the following conditions:

$$
y\left(d_{i}, C_{j}\right)\left\{\begin{array}{l}
1, d_{i} \in C_{j} \\
0, d_{i} \notin C_{j}
\end{array}\right.
$$

\section{Evaluation}

At this stage, testing will be carried out. The purpose of the test is to find out how far the performance of the model built (Borman et al., 2018). At this stage the algorithm or model developed will be tested for its effectiveness. The test carried out is to measure the level of accuracy. To test the accuracy use the following equation:

$$
\text { Accuracy }=\frac{T P}{C P} \times 100 \%
$$

Where, TP is obtained from the total number that is classified and $\mathrm{CP}$ is the number of the correct classification results.

\section{RESULT}

Classification of broadleaf weeds uses a combination of KNN and PCA algorithms developed and implemented with Matlab. The GUI application was developed to make it easier for users to use it. The initial process is to build a program that is used for training. After that, built a program that is used for testing. The system starts by resizing and cropping the image as needed. Then the inputted image is converted into a binary image to facilitate the segmentation process. Fig. 2 shows the transformation process from the original image to a binary image. 


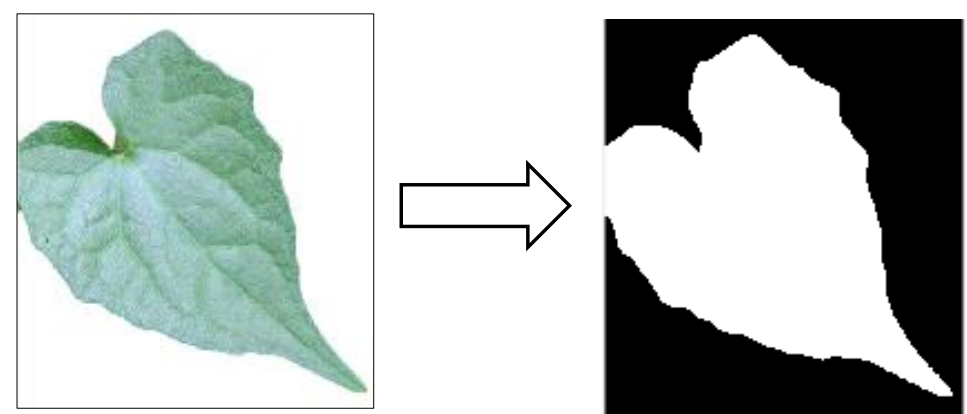

Fig. 2 Transformation from Original Image to Binary

The next stage is image segmentation. The purpose of the image segmentation above is to separate the object from the background. After the image is segmented, it will facilitate the feature extraction process. In this study using thresholding for image segmentation. After the image is segmented, PCA will perform a large data space transformation which will obtain an orthonormal basis vector which includes the eigenvectors of a certain covariance matrix to produce an optimal data distribution. Figure 3 is the result of image segmentation performed on one of the image samples that have been carried out.

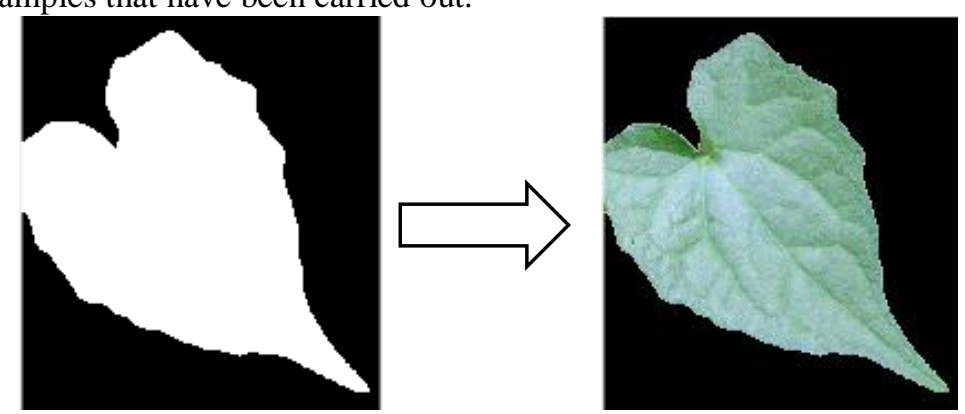

Fig. 3 Image Segmentation Results

Furthermore, for the classification process using the KNN algorithm. KNN classifies objects by paying attention to the data closest to the object being processed. This system was developed using Matlab. Fig. 4 below is a GUI of the broadleaf weed classification system developed using Matlab.

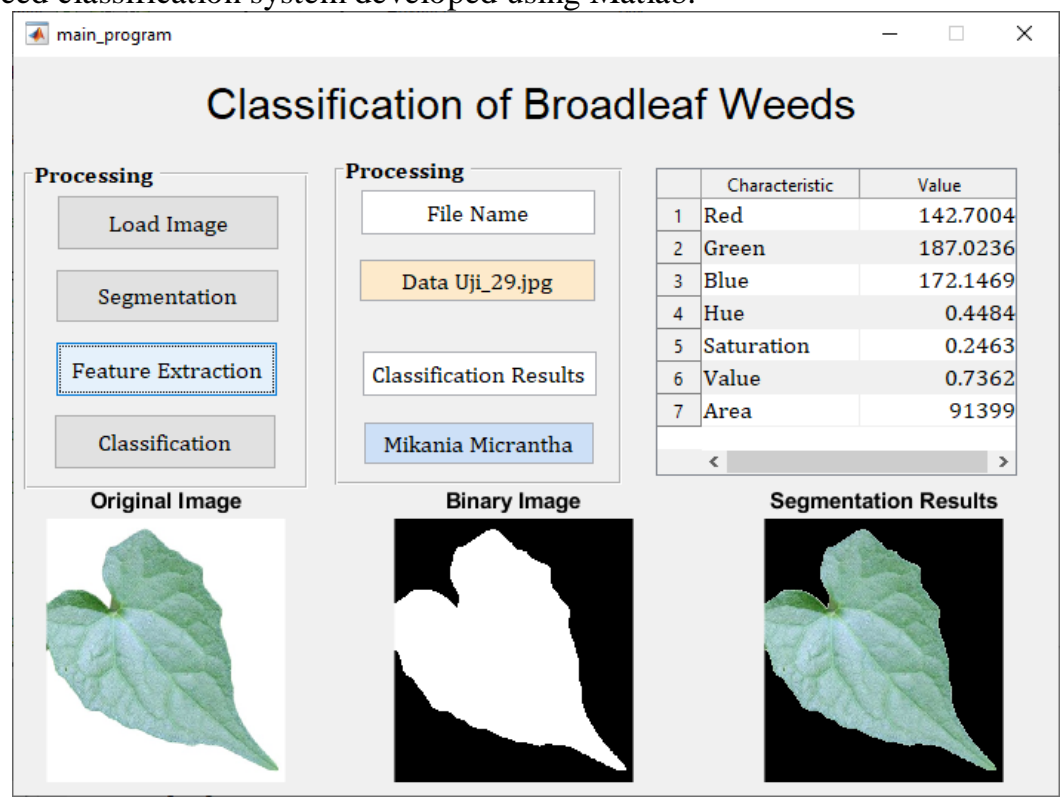

Fig. 4 GUI Display of Broadleaf Weed Classification System

After the GUI application is built, the accuracy of the developed model is then tested. The system will be tested for accuracy using equation (10) which has been discussed previously. The test data used are 80 test data. There are 4 classes or categories of weeds used, namely Mikania micrantha, Ageratum conyzoides, Asystasia gangetica *name of corresponding author 
and Borreria alata. Each class is each tested with 20 images. All test images will be matched with the classification results. The test results on the accuracy of the model can be seen in Fig. 5 in the form of a graph of the percentage of accuracy test results for each class or category of broadleaf weeds.

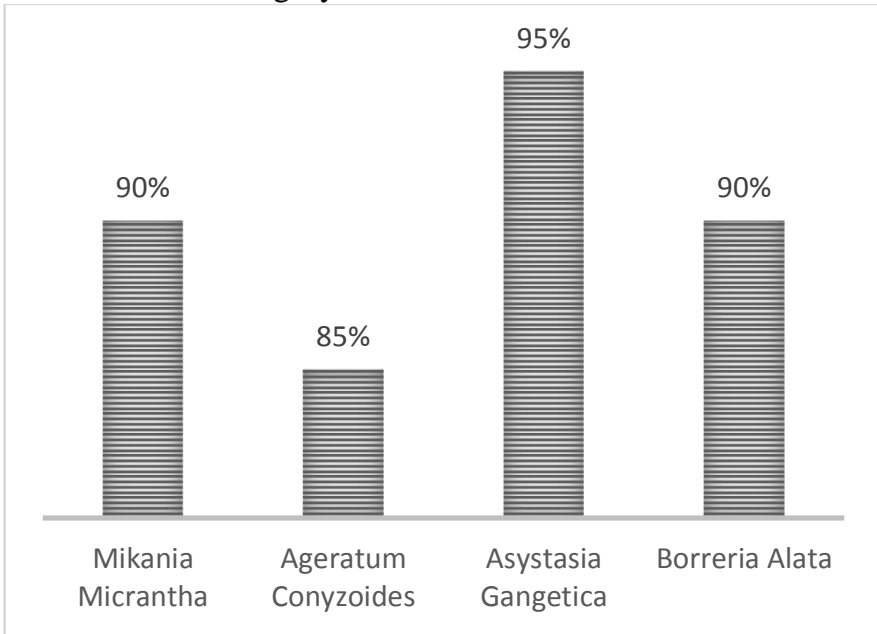

Fig. 5 Accuracy Test Result Presentation Graph

\section{DISCUSSIONS}

Based on Figure 2, the accuracy test results show that each broadleaf weed classification has accuracy values, namely: Mikania micrantha by $90 \%$, Ageratum conyzoides by $85 \%$, Asystasia gangetica by $95 \%$ and Borreria alata by $90 \%$. These results can be included in the classification results category with conversion values: Good, with a value of $76 \%-100 \%$; Enough, with a value of $56 \%-75 \%$; Less Good, with a value of $40 \%-55 \%$, while Less Good, has a value of less than $40 \%$ (Borman \& Purwanto, 2019). When viewed from the average accuracy obtained from the identification accuracy percentage of $90 \%$, it is included in the good category. These results are influenced by several factors, including the classification can be optimal if feature extraction is able to provide optimal information, feature extraction is based on color and shape then the results of feature extraction are converted into main components and reduced to main components. This can facilitate the classification process. Furthermore, $\mathrm{KNN}$ can perform a classification based on the number of nearest neighbors. However, when viewed from the results of the accuracy test, the average error reaches $10 \%$. Based on the test results, it is known that there are several factors that cause model errors in classification, including: (1) the amount of training data and test data is too small so it needs to be added because the more models that are trained, the more models are trained. will be more optimal; (2) the model is difficult to classify if the leaves are clustered and the classified image displays the image clearly; (3) the background of the object also affects the results of the classification.

\section{CONCLUSION}

This study resulted in a broadleaf weed classification system using a combination of the K-Nearest Neighbor $(\mathrm{KNN})$ and Principal Component Analysis (PCA) algorithms. Based on the test results, the developed model is able to produce an accuracy of $90 \%$. Principal Component Analysis (PCA) and K-Nearest Neighbor (KNN) algorithms can be used in the classification process properly. The number of datasets and image quality can affect the classification results. For this reason, further research can increase the amount of training data and test data and use a deep learning approach so that the classification results can be more optimal.

\section{REFERENCES}

Agustin, S., \& Dijaya, R. (2019). Beef Image Classification using K-Nearest Neighbor Algorithm for Identification Quality and Freshness. ICCOMSET 2018. https://doi.org/10.1088/1742-6596/1179/1/012184

Alkababji, A. M., \& Jbaar, M. A. Al. (2021). Iris Re-Identification Using Stationary Wavelet Transform (SWT), Principal Component Analysis and KNN Classifier. Turkish Journal of Physiotherapy and Rehabilitation, 32(3), 8224-8230.

Andrian, R., Maharani, D., Muhammad, M. A., \& Junaidi, A. (2020). Butterfly Identification Using Gray Level Co-Occurrence Matrix (GLCM) Extraction Feature and K-Nearest Neighbor (KNN) Classification. Register: Jurnal Ilmiah Teknologi Sistem Informasi, 6(1), 11-21. https://doi.org/10.26594/register.v6i1.1602

Borman, R. I., Napianto, R., Nugroho, N., Pasha, D., Rahmanto, Y., \& Yudoutomo, Y. E. P. (2021).

*name of corresponding author 
Implementation of PCA and KNN Algorithms in the Classification of Indonesian Medicinal Plants. ICOMITEE 2021, 46-50. IEEE.

Borman, R. I., Priopradono, B., \& Syah, A. R. (2017). Klasifikasi Objek Kode Tangan pada Pengenalan Isyarat Alphabet Bahasa Isyarat Indonesia (Bisindo). Seminar Nasional Informatika Dan Aplikasinya (SNIA), (September), 1-4.

Borman, R. I., \& Priyopradono, B. (2018). Implementasi Penerjemah Bahasa Isyarat Pada Bahasa Isyarat Indonesia (BISINDO) Dengan Metode Principal Component Analysis (PCA). Jurnal Informatika: Jurnal Pengembangan IT (JPIT), 03(1), 103-108.

Borman, R. I., \& Purwanto, Y. (2019). Impelementasi Multimedia Development Life Cycle pada Pengembangan Game Edukasi Pengenalan Bahaya Sampah pada Anak. Jurnal Edukasi Dan Penelitian Informatika (JEPIN), 5(2), 119. https://doi.org/10.26418/jp.v5i2.25997

Borman, R. I., Putra, Y. P., Fernando, Y., Kurniawan, D. E., Prasetyawan, P., \& Ahmad, I. (2018). Designing an Android-based Space Travel Application Trough Virtual Reality for Teaching Media. Proceedings of the 2018 International Conference on Applied Engineering, ICAE. https://doi.org/10.1109/INCAE.2018.8579394

Borman, R. I., Rossi, F., Jusman, Y., Rahni, A. A. A., Putra, S. D., \& Herdiansah, A. (2021). Identification of Herbal Leaf Types Based on Their Image Using First Order Feature Extraction and Multiclass SVM Algorithm. 1st International Conference on Electronic and Electrical Engineering and Intelligent System (ICE3IS) Identification, 12-17. IEEE.

Borman, R. I., \& Wati, M. (2020). Penerapan Data Maining Dalam Klasifikasi Data Anggota Kopdit Sejahtera Bandarlampung Dengan Algoritma Naïve Bayes. Jurnal Ilmiah Fakultas Ilmu Komputer, 9(1), 25-34.

Chen, Y., Song, L., Liu, Y., Yang, L., \& Li, D. (2020). A Review of the Artificial Neural Network Models for Water Quality Prediction. Applied Sciences, 10(5776), 1-49.

Dahlianah, I. (2019). Keanekaragaman Jenis Gulma Di Perkebunan Kelapa Sawit Desa Manggaraya Kecamatan Tanjung Lago Kabupaten Banyuasin. $\quad$ Indobiosains, $\quad 1(1), \quad 30-37$. https://doi.org/10.31851/indobiosains.v1i1.2296

Dix, S., \& Müller, P. (2021). Digital Image Processing Methods for The Evaluation of Optical Anisotropy Effects in Tempered Architectural Glass Using Photoelastic Measurements. Glass Structures \& Engineering, 6(1), 3-19. https://doi.org/10.1007/s40940-020-00145-3

Imaniasita, V., Liana, T., \& Pamungkas, D. S. (2020). Identifikasi Keragaman dan Dominansi Gulma pada Lahan Pertanaman Kedelai. Agrotechnology Research Journal, 4(1), 11-16. https://doi.org/10.20961/agrotechresj.v4i1.36449

Ionel-bujorel, P., Ancuceanu, R., Enache, C., \& Vasilăţeanu, A. (2017). Important Shape Features for Romanian Medicinal Herb Identification Based on Leaf Image. The 6th IEEE International Conference on E-Health and Bioengineering - EHB, 599-602. IEEE.

Justiawan, J., Sigit, R., \& Arief, Z. (2017). Tooth Color Detection Using PCA and KNN Classifier Algorithm Based on Color Moment. EMITTER International Journal of Engineering Technology, 5(1), 139-153.

Lee, S. L., \& Tseng, C. C. (2018). Digital Image Sharpening Using Integral Image Representation and Laplacian Operator. 2018 IEEE International Conference on Consumer Electronics-Taiwan, ICCE-TW 2018, 31-32. https://doi.org/10.1109/ICCE-China.2018.8448488

Li, R., Ji, S., Shen, S., Li, P., Wang, X., Xie, T., ... Wang, Z. (2019). Arrhythmia Multiple Categories Recognition based on PCA-KNN Clustering Model. The 8th IEEE International Symposium on Next-Generation Electronics. IEEE.

Lubis, Z., Sihombing, P., \& Mawengkang, H. (2020). Optimization of K Value at the K-NN algorithm in clustering using the expectation maximization algorithm. IOP Conf. Series: Materials Science and Engineering, 725. https://doi.org/10.1088/1757-899X/725/1/012133

Mulyanto, A., Borman, R. I., Prasetyawan, P., Jatmiko, W., Mursanto, P., \& Sinaga, A. (2020). Indonesian Traffic Sign Recognition For Advanced Driver Assistent (ADAS) Using YOLOv4. 2020 3rd International Seminar on Research of Information Technology and Intelligent Systems (ISRITI), 520-524. Retrieved from file://C:/Users/CPU/AppData/Local/Mendeley Ltd./Mendeley Desktop/Downloaded/Mulyanto et al. - 2020 - Indonesian Traffic Sign Recognition For Advanced Driver Assistent (ADAS) Using YOLOv4.pdf

Nikita, N., Sadawarti, H., \& Kaur, B. (2020). Classification of Renal Cancer using Principal Component Analysis (PCA) and K-Nearest Neighbour (KNN). International Journal of Engineering Research \& Technology (IJERT), 8(16), 156-159.

Pradhana, M. A. (2020). Analisis Perubahan Sikap Uni Eropa Terhadap Impor Minyak Kelapa Sawit Indonesia. Journal of International Relations, 6(4), 525-534.

Prasetyawan, P., Ahmad, I., Borman, R. I., Ardiansyah, A., Pahlevi, Y. A., \& Kurniawan, D. E. (2018).

*name of corresponding author 
Classification of the Period Undergraduate Study Using Back-propagation Neural Network. Proceedings of the 2018 International Conference on Applied Engineering, ICAE 2018. https://doi.org/10.1109/INCAE.2018.8579389

Saleh, A., Dibisono, M. Y., \& Gea, S. U. (2020). Keragaman Gulma Pada Tanaman Kelapa Sawit (Elaies guineensis Jacq.) Belum Menhasilkan dan Sudah Menghasilkan di Kebun Rambutan PT. Perkebunan Nusantara III. Agro Estate, 4(1), 1-10.

Sanjaya, S., Pura, M. L., Gusti, S. K., Yanto, F., \& Syafria, F. (2019). K-Nearest Neighbor for Classification of Tomato Maturity Level Based on Hue, Saturation, and Value Colors. Indonesian Journal of Artificial Intelligence and Data Mining, 2(2), 101. https://doi.org/10.24014/ijaidm.v2i2.7975

Tanjung, J. P., \& Wijaya, B. A. (2020). Facial Recognition Implementation using K-NN and PCA Feature Extraction in Attendance System. SinkrOn : Jurnal Dan Penelitian Teknik Informatika, 5(1), 43-50.

Vaishnnave, M. P., Devi, K. S., Srinivasan, P., \& Jothi, G. A. P. (2019). Detection and Classification of Groundnut Leaf Diseases Diseases Using KNN Classifier. Proceeding of International Conference on Systems Computation Aatomation and Networking.

Wirdiani, N. K. A., Hridayami, P., Widiari, N. P. A., Rismawan, K. D., Candradinata, P. B., \& Jayantha, I. P. D. (2019). Face Identification Based on K-Nearest Neighbor. Scientific Journal of Informatics, 6(2), 150-159. https://doi.org/10.15294/sji.v6i2.19503

*name of corresponding author 